\title{
Durability study of stiffened composite panels subject to compressive loads in the plan and post buckling regime
}

\author{
Estudo da durabilidade de painéis compósitos reforçados sujeitos a \\ cargas compressivas no plano e regime pós-flambagem
}

Arthur Scaglioni Oliveira1, Ricardo Francisco Gouvea ${ }^{1,2}$, Mariano Andrés Arbelo1, Maurício Vicente Donadon¹,

Rita de Cássia Mendonça Sales ${ }^{1,2}$

\section{ABSTRACT}

The aim of this work was the study of the durability of stiffened composite panels submitted to the post-buckling regime under compressive loads. The study was based on fatigue test using compression loads in specimens made with initial failures in the bonded area. To monitor the delamination process, the ultrasonography technique was used as a non-destructible test. In the end, it was possible to observe the relationship between delamination propagation and the quantity of cyclic loads that the material supports. It was concluded that the stiffened panels supported a series of cycles with a low rate of delamination propagation. This shows that the applications of these materials as aeronautical structures are safe.

Keywords: Delamination, Aeronautical panels, Compression loads, Bonded joints, Fatigue, Durability.

\section{RESUMO}

O objetivo deste trabalho foi o estudo da durabilidade dos painéis de fibra de carbono/epóxi reforçados e colados submetidos ao regime pós-flambagem sob cargas compressivas. O estudo baseou-se no teste de fadiga utilizando cargas de compressão nos espécimes feitos com falhas iniciais na região de colagem. Para monitorar o processo de delaminação, a técnica de ultrassonografia foi utilizada como teste não destrutível. No final, foi possivel observar a relação entre a propagação de delaminação e a quantidade de cargas cíclicas suportadas pelo material. Concluiu-se que os painéis reforçados suportaram uma série de ciclos com baixa taxa de propagação de delaminação. Isso mostra que as aplicações desses materiais como estruturas aeronáuticas são seguras.

Palavras-chave: Delaminação, Painel aeronáutico, Cargas de compressão, Juntas coladas, Fadiga, Durabilidade.

\footnotetext{
'Faculdade de Tecnologia de São José dos Campos - Professor Jessen Vidal - São José dos Campos/SP - Brazil. ${ }^{2}$ Instituto Tecnológico de Aeronáutica - Departamento de Aeronáutica - Laboratório de Estruturas - São José dos Campos/SP - Brazil. Corresponding author: Rita de Cássia Mendonça Sales | Faculdade de Tecnologia de São José dos Campos - Professor Jessen Vidal | Av. Cesare Mansueto Giulio Lattes, 1350 | CEP 12.247-014 - São José dos Campos/SP - Brazil | E-mail: rita.sales@fatec.sp.gov.br

Received: Feb. 15, 2018 | Accepted: Mar. 23, 2018
} 


\section{INTRODUCTION}

In the design of an aircraft project, one of the influencing factors is the choice of the best material in relation to its performance combined with the weight relief to increase the aircraft power. Because of this, the aircraft industry has largely utilized advanced composites for the development of its aircrafts by its high mechanical performance in strength, hardness, and low density, compared to metals.

The increasing use of polymers reinforced with carbon fiber in the aeronautical industry is due mainly to the constant challenge of this industry in obtaining components that exhibit the highest values of mechanical strength and specific hardness among the available materials. According to Rezende and Botelho ${ }^{1}$, the exchange of aluminum by structural polymer composites, for example, allows a weight reduction of $20 \%$ to $30 \%$, plus a $25 \%$ reduction in the final cost of pieces.

Librantz et al. ${ }^{2}$ shows that composite or conjugate materials are combinations of two or more materials. Most of these materials consist of a reinforcing element dispersed in a matrix, resulting in a bonding resin, in order to obtain specific characteristics and desired properties.

To manufacture the structures in a single piece is in many cases impractical. Usually it becomes necessary to divide the structure into smaller parts to be manufactured and then, to make the assembly of the structure. To accomplish this set, mechanical joints can be used, such as screws and rivets. Other possibility is the use of bonding technique, since it has several advantages over the mechanical joints. An outstanding advantage, for the aeronautical industry, is that the bonded joints have a better surface finish, in other words, they reduce the disturbance of the airflow, which results in less drag. Another relevant advantage of a bonded joint is that it has a fatigue life longer than a mechanical joint, which has stress-tightening holes ${ }^{3}$.

Ribeiro $^{3}$ presents in his work the bonded joints following advantages: better efficiency in the load transfer, better surface finishing (generating less drag), better sealing, better resistance to fatigue, and better aerodynamic efficiency. However, it has some drawbacks, such as the surface preparation for the joint adhesive is critical for its mechanical resistance, it is not removable, there are no efficient non-destructive tests to ensure the joint quality, and the capacity and resistance to high temperatures is limited.

According to Astrom ${ }^{4}$ and Yao et al. ${ }^{5}$, fatigue delamination is one of the most critical failure modes in carbon fiber composite. It can gradually cause loss of mechanical resistance and hardness, and cause catastrophic failure of the component during its life.

Another important modeling issue is the fatigue life of the composite. In contrast to homogeneous materials, which fatigue failure generally occurs by initiating and propagating a single crack, the fatigue process in composite materials is very complex and involves various types of damage including fiber/matrix debonding, matrix crack, delamination, and fiber fracture (tension failure or compression in the form of fiber microbuckling or kinking).

The airplane fuselage is a typical example of design with this philosophy. Most studies of buckling and post buckling in composite structures are associated with the fuselage design. The parts and components development from composite materials that are efficient in weight and cost in relation to metal parts implies the need of a thorough knowledge of these new structures behavior, when subjected to service loads. Therefore, the purpose of this project is to study the behavior in the post-buckling regime in stiffened composite panels in order to characterize the buckling modes, to determine the loads and failure modes in aeronautical panels made of composite materials, and to determine its durability.

\section{MATERIALS AND METHODS Specimen Preparation}

For the execution of the fatigue tests subject to compression load (Fig. 1), the laminated carbon fiber was made in directions $0^{\circ}$ and $45^{\circ}$ one layer of carbon fiber fabric pre-impregnated with epoxy resin $\left(45^{\circ}\right)$ and two layers of one-direction fabric impregnated with epoxy resin $\left(0^{\circ}\right)$. A Teflon ${ }^{\circledR}$ insert, with a size of $50 \mathrm{~mm}$, was purposely inserted in the interface between stiffener and panel in the central position of the panel.

To perform the tests there were two specimens (AM1 and AM2), one for the static test used to determine limits loads, and other for the characterization of the initial crack spread by means of fatigue tests.

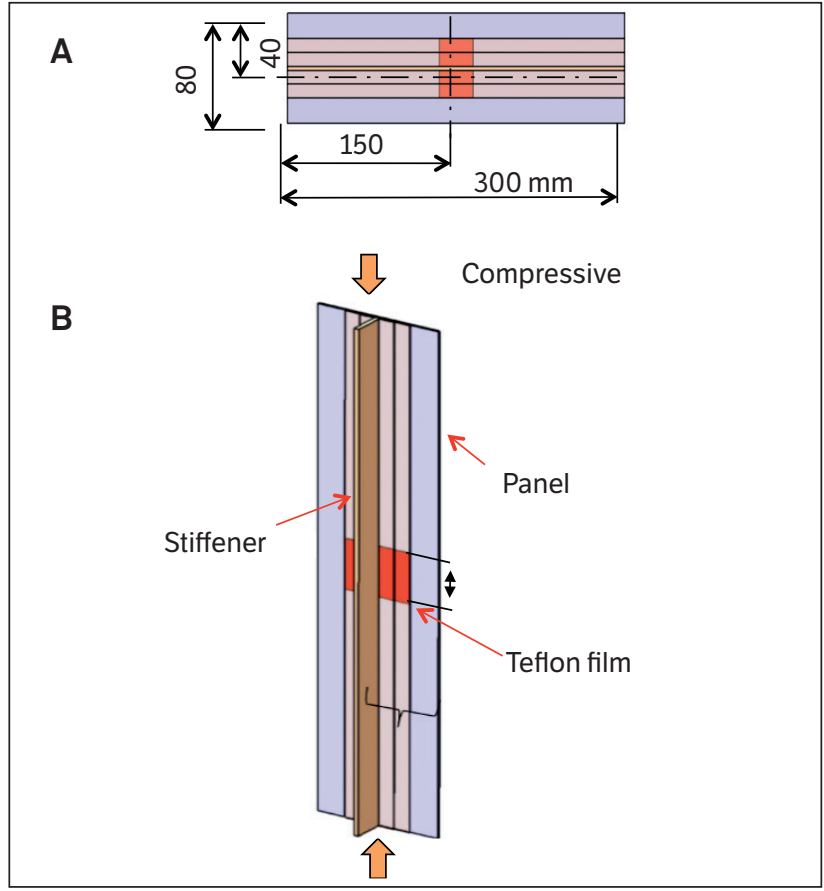

Figure 1: (A) Specimen dimensions used for compression tests. Detail of the stiffener and the Teflon film positioning in the Panel ( ) specimen in three dimensions and direction of the loads. 
For better loads distribution, the load blocks were fixed with LOCTITE 406 cyanoacrylate adhesive with an L-shaped tool on both sides of the specimen ends. Figure 2 shows the layout of the blocks on the specimen faces.

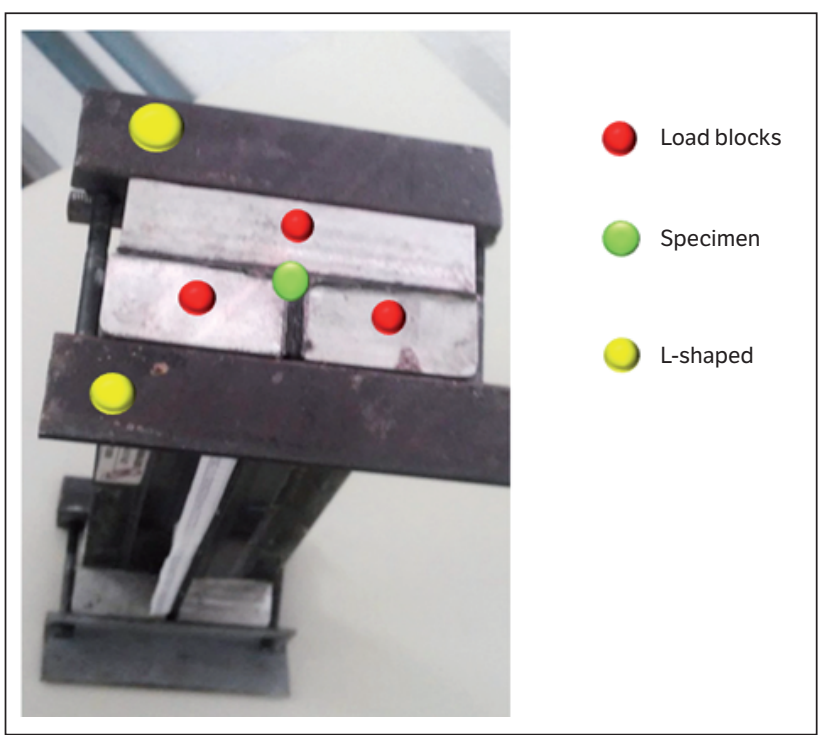

Figure 2: Load blocks arrangement in the specimen.

\section{Ultrasound Scanner}

The specimens were analyzed before and after the buckling tests by ultrasound using the pulse-echo technique. For the specimens' qualification, ISONIC 2006 manual equipment and a nominal $5 \mathrm{MHz}$ specific transducer for composite materials were used. This equipment has a low frequency radio wave emitting device that transmits the waves for two other receiver devices fixed in a marked ruler, forming a triangulation signal transmission system, making it possible to scan parts using C-Scan type image generation.

At the end of the specimen scan, an image post-processing was performed, defining the size of the initial crack. For a more accurate monitoring of the total delamination dimensions between stiffener and the panel, ultrasound scans were performed every 3,000 cycles and after the statical tests.

\section{Tests of Durability}

Durability tests were conducted at a loading frequency of $1 \mathrm{~Hz}$, maximum $20 \mathrm{kN}$ compression load and minimum $10 \mathrm{kN}$ at room temperature $\left(25^{\circ} \mathrm{C}\right)$, in a universal servo-hydraulics system for mechanical testing, MTS Landmark model with capacity Maximum load of $100 \mathrm{kN}$ located in the ITA laboratory. Specimens were submitted to 60,000 load cycles and the tests were interrupted each 3,000 cycles to monitor the propagation of the delamination in the panel/stiffener interface via ultrasound inspection (C-Scan). After each inspection, the specimens were loaded with an almost static form load up to the post-buckling regimen to check the effects of fatigue-induced damage on the residual hardness of the panels.

\section{Microscopy}

At the end of 30,000 cycles, it was observed that it had started a crack in the stiffener. Ultrasound analysis cannot be used to follow this new crack in the stiffener due to geometric restriction of the ultrasound probe and panel.

To study this new crack formation, it was used a Stereoscopic Olympus SZ61. For better monitoring of the crack during microscopic analysis, a millimetric scale was placed with an initial point in the half of the reinforcing length, attached to the side of the stiffener (Fig. 3).

\section{RESULTS AND DISCUSSION Static Test Results}

Figure 4a shows the load curves versus displacement for specimens tested in compression loads. When the panel is compressed, a gap is observed in the region where the initial crack was inserted (Fig. 4b), at this time the propagation of the delamination between the stiffener and the panel begins. It is understood that the mode of failure is in mode I (opening) and at the end of the crack in mode II, where occurs the layers compression of the stiffener and the panel. The specimen subjected to the compression load on the plane revealed that the local buckling of the panel occurs at load levels around $40 \%$ of the global buckling load. The load needed for local buckling was

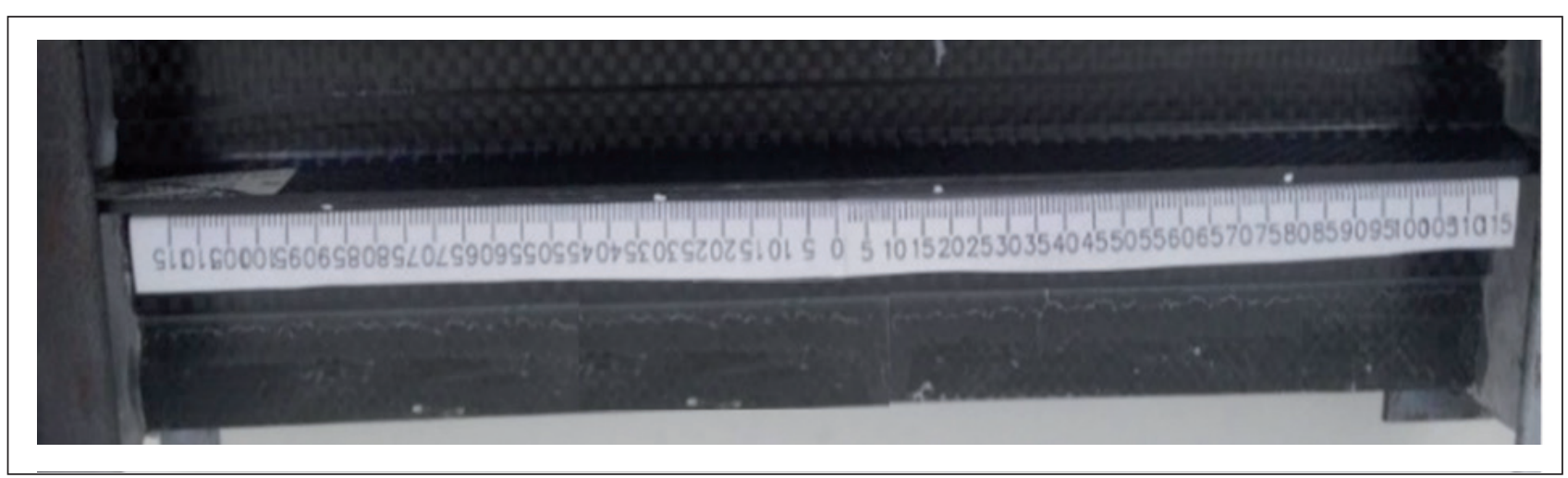

Figure 3: Specimen with millimetric scale. 
$13 \mathrm{kN}$ and for a global buckling until the breakup was $33 \mathrm{kN}$. Figure $4 \mathrm{c}$ shows the rupture in the AM1 stiffener after the static compression test.

\section{Fatigue Results}

When the AM1 was tested statically, the material failure is clearly understood, but to determine the total extension of the delamination, an ultrasound analysis was performed after the AM1 was tested (Fig. 5a).
Several ultrasound analyses were made for the followup on the AM2; all the results were used to determine the delamination by quantity of cycles. Figure $5 \mathrm{~b}$ presents the final crack of the AM2 after 60,000 cycles. The durability results were satisfactory, indicating that the material presented low rate of delamination propagation (about $2 \mathrm{~mm}$ every 3,000 cycles) showing up fit for the application that was designed. Figure 6 shows the delamination of the material by the amount of cycles tested.
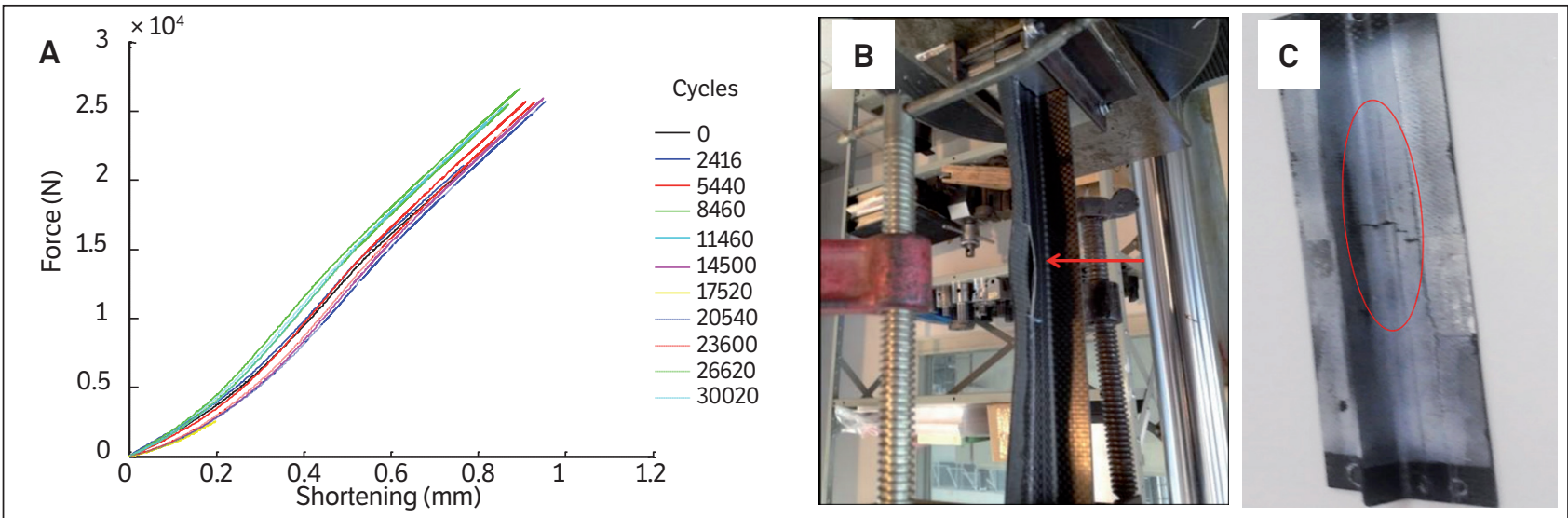

Figure 4: (A) Load versus displacement results for compression tests; (B) opening of the cracks during the compression test (AM1); and (C) magnification of stiffener failure in AM1.
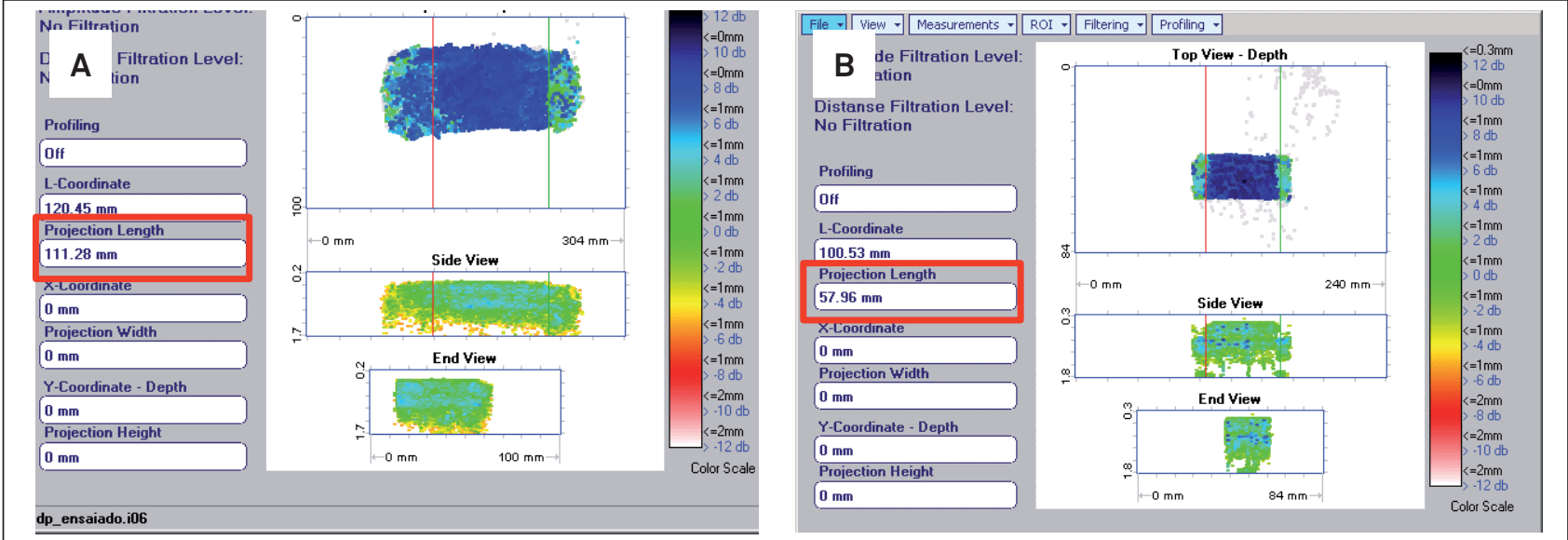

Figure 5: Ultrasound analysis result of AM1 (A) after static test; and (B) after 60,000 cycles.

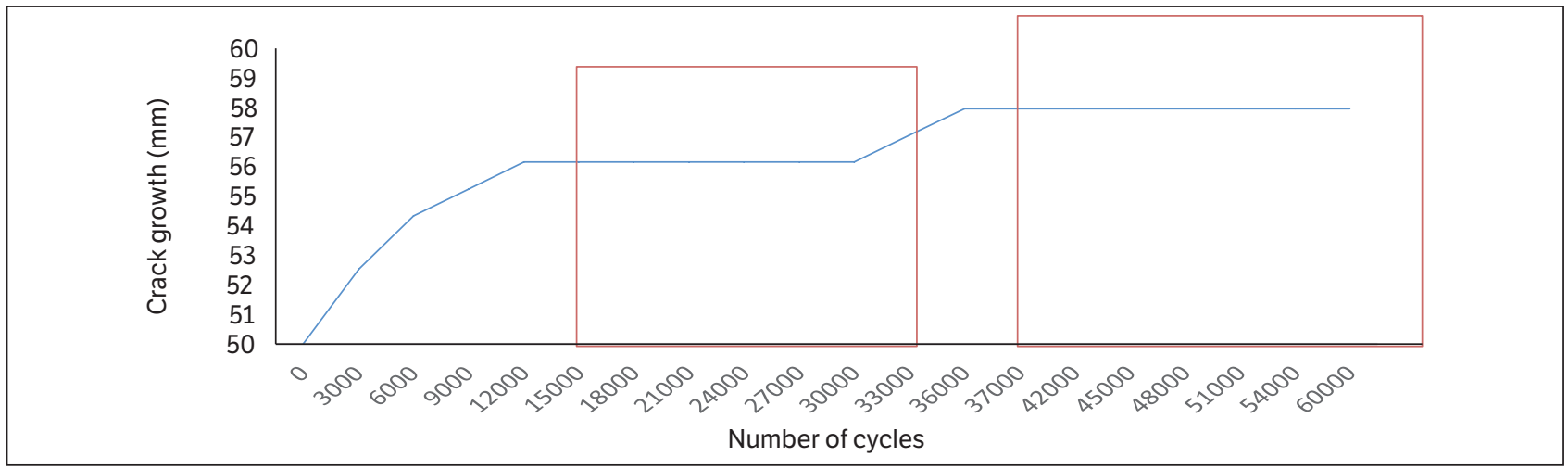

Figure 6: Crack growth $\times$ number of cycles. 


\section{Microscopy Results}

To understand the delamination stagnation (regions highlighted in Fig. 6), as the increase of cycle loads, a microscopic analysis on failure was performed. In the first plateau region no apparent failure was detected by microscopic or by ultrasound analyses. At the end of 30,000 cycles, it was observed that a crack had started in the stiffener. It is probably because, in the first plateau (Fig. 6), the crack growth occurred between the interface panel/stiffener and none of the techniques used were capable to detect this crack path migration. Then, the plateaus showed in Fig. 6, indicating changes in the crack path that dissipate the energy of the loading cycles during the delamination process. The appearance of this crack in the stiffener may have been caused by voids or failures formed during the manufacturing process of the stiffener, significantly diminishing its resistance, initiating a delamination process.

Figure 7 shows the image of the delamination growth in the stiffener. It can be observed that the crack is $2 \mathrm{~mm}$ bigger after the end of the fatigue tests $(60,000$ cycles $)$.

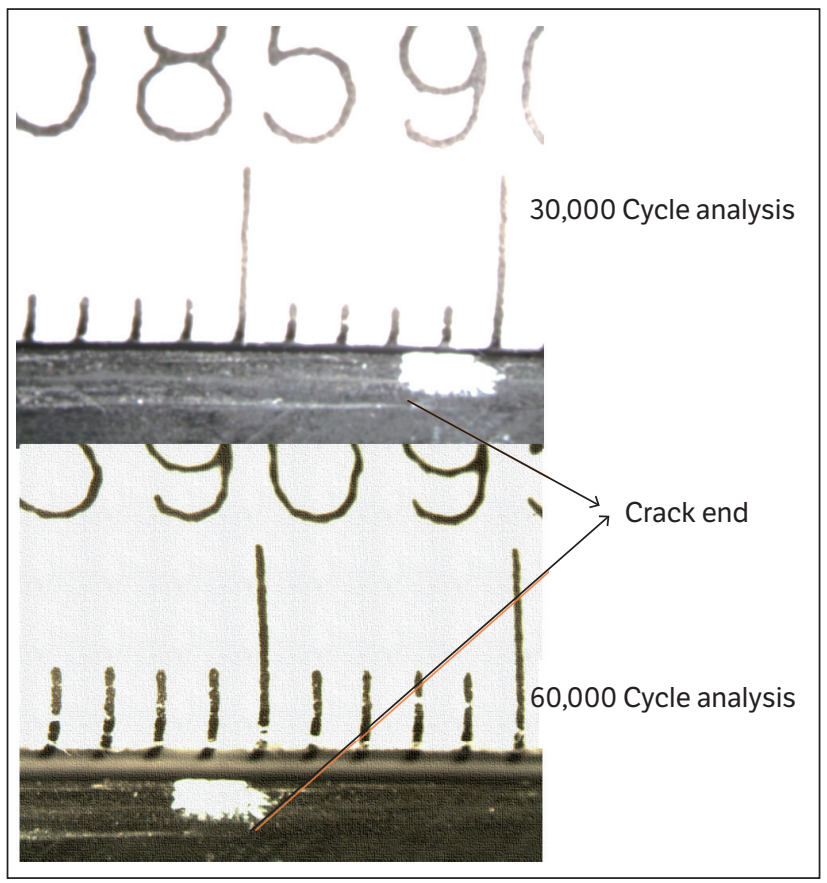

Figure 7: Comparison of delamination growth between 30,000 cycles and 60,000 cycles.

\section{CONCLUSION}

The stagnation of the delamination between the layers of the panel and the stiffener when obtaining 12,000 to 30,000 cycles and 36,000 to 60,000 cycles can be justified because the crack started in the specimen stiffener. The energy applied during the cyclical loads has been dissipated in this other crack initiated in the stiffener. The start of the stiffener's crack may be justified by the material's manufacturing process. It is probable that, during the specimen manufacturing, some voids may have been formed decreasing significantly the local resistance of the composite. This failure process could have detached the stiffener from the panel and formed two separated rigid bodies. Thus, there was concentration of tension in the stiffener, weakening the stiffener and starting a crack in the unwanted place.

\section{ACKNOWLEDGEMENTS}

Thanks to CNPq for the scholarship of PIBIT (154974/2015-3), to FAPESP (2017/13959-5), and to the Laboratory of Structures of ITA for making available all tools and equipment for the accomplishment of this work.

\section{REFERENCES}

1. Rezende MC, Botelho EC. O Uso de Compósitos Estruturais na Indústria Aeroespacial. Polímeros. 2000;10(2):e4-e10. Available from: http://dx.doi.org/10.1590/S0104-14282000000200003

2. Librantz H, Rambo CR, Librantz AFH. Efeitos do impacto dos raios nas aeronaves com estrutura em materiais compósitos. Exacta. 2006;4(2):259-271. Available from: http://www.redalyc. org/articulo.oa?id=81040205

3. Ribeiro ML. Programa para Análise de Juntas Coladas: Compósito/Compósito e Metal/Compósito [PhD thesis]. São Carlos: Universidade de São Paulo; 2009.

4. Astrom BT. Manufacturing of polymer composites. London: Chapman and Hall; 1997.

5. Yao L, Alderliesten R, Zhao M, Benedictus R. Bridging effect on mode I fatigue delamination behavior in composite laminates. Composites Part A: Applied Science and Manufacturing. 2014;63:103-109. Available from: https://doi.org/10.1016/j. compositesa.2014.04.007 